\title{
Sosyal Bilimlerde Bir Disiplin Olma Sürecinde İletişim Bilimleri ve Felsefe İlişkisi
}

\author{
GÖKSEL AYMAZ \\ gokselaymaz@gmail.com \\ ORCID ID: 0000-0002-3520-0163
}

\begin{abstract}
Öz: Sosyal bilimler içinde kendini özgün bir disiplin olarak geliştirme yönünde ilerleyen iletişim bilimleri, felsefe ile henüz doğru bir ilişki kuramamıştır. Fakat bu sorun, sosyal bilimlerde "olgu"nun tanımlanmasına ilişkin epistemolojik güçlükten gelen genel bir sorundur. Sosyal bilimlerdeki "pozitivist", konvansiyonalist" ve "realist" epistemolojilere karşıllk gelen "izleyici araştırmaları", "söylem analizi" ve "eleştirel yaklaşım" gelenekleri, iletişim araştırmalarının felsefeyle ilişkisindeki farkl perspektifleri ifade eder. Makalemizde, kitle iletişim teorisinin bıraktığ sunmakta olduğu ortaya konulmaktadır. Bu çeşitlilik içerisinde, kendini özgün bir disiplin olarak konumlandırma arzusundaki iletişim bilimlerinin onu felsefeyle yakın ilişkiye sokacak perspektifi benimsemek durumunda olduğu öne sürülmektedir. Bunun dayană̆ı olarak, sosyal bilimlerin kökensel olarak bir "sosyal olgu" bilimi değil, "sosyal oluş" bilimi olduğu gerçeğinden hareketle, olguların alanı olan iletişim biliminin ilkelerin alanı olan felsefe ile her zaman yakın ilişki içinde olması gerektiği söylenmektedir. Bu bağlamda, "realist" epistemoloji ve "eleştirel yaklaşım" önerilmektedir.
\end{abstract}

Anahtar kelimeler: İletişim bilimleri, Felsefe, Sosyal bilimler, Olgu, Epistemoloji.

\section{Giriş}

İletişim araştırmalarının başlangıcı olarak kabul edilen, okuryazarlığın arttığı, günlük gazetelerin yaygınlaştığı on dokuzuncu yüzyılda, kitlesel medyanın, toplumun duygularını "akıldışı bir kalabalığın karakteristiklerini gösterdiği bir noktaya kadar körükleme yetisinin bir kanıtı” olmuş olan ünlü Dreyfus davası ${ }^{1}$, ahlâk ve siyaset felsefesinden bağımsız düşünülebilir mi? Veya, dijital teknolojinin görsel, işitsel, yazınsal bazı veri yapılarını ve pek çok unsuru "ağ ortamı” içerisinde bir araya getirerek ağ kullanıcılarını "sanal uzamın zamansız katmanında" birbirlerine erişimlerini sağlayarak iletişime sokan "hipermedya”2, varlık felsefesinin ilgi alanı dışında

\footnotetext{
* Dr. Öğr. Üyesi, Marmara Üniversitesi, İletişim Fakültesi.

1 Kurt Lang, "İletişim Araştırmaları: Kökenleri ve Gelişmesi”, Erol Mutlu (der. ve çev.), Kitle İletişim Kuramları, Ankara: Ütopya Yayınları, 2005, s.29.

2 Manuel Castells, Enformasyon Çağı: Ekonomi, Toplum ve Kültür Cilt 1: Ağ Toplumunun Yükselişi, çev., Ebru Kılıç, İstanbul: Bilgi Üniversitesi Yayınları, 2005, s.59 ve 609.
} 
tutulabilir mi? Aslında en genel düzeyde şunu sormak gerekir: Sosyal bilimler içinde kendini özgün bir disiplin olarak geliştirme yönünde ilerleyen iletişim bilimlerinin, birçok özgül hipoteze sahipken, "atom tablosu veya evrim gibi büyük bir kuramın yokluğundan” sıklıkla yakınması ${ }^{3}$, onun felsefe ile henüz doğru bir ilişki kuramamış olduğunu göstermez mi, alanda büyük bir kuramın yokluğu alanın felsefe ile olan ilişkisiyle alâkalı değil midir?

Örneklerden de anlaşılacağı üzere, iletişim bilimleri ile felsefe birbirleriyle ilgili alanlardır fakat aralarında bu ilginin gerektirdiği tarzda ve nitelikte doğru bir ilişki henüz kurulamamıştır. Bu sorun, esasen, iletişim bilimlerinin de içinde yer aldığ 1 sosyal bilimlere ait genel bir sorundur, sosyal bilimlerin felsefe ile doğru bir ilişki kuramamış olmasindan kaynaklanan bir sorundur.

İletişim konusu, modern toplumları kendisine araştırma nesnesi yapmış olan sosyal bilimlerin ilgi alanına biraz gecikerek girdi. Oysaki modern dünya dediğimiz günümüz gerçekliği, yerkürenin insani deneyimler açısından bütünleşmiş tek bir mekân haline gelişiyle karakterize olmuştur ve bu ise Gutenberg matbaasından itibaren, gelişiminde kitle iletişim araçlarının önemli pay sahibi olduğu bir süreçtir. Bu nedenle, aslında modern dünyanın araştırılmasında medyaya merkezi bir yer vermek gerekiyordu. ${ }^{4}$ Böyle olmasına rağmen, sosyal bilimler için kitle iletişim araçları televizyon çağına kadar marjinal bir konu olarak kaldı. O zamana dek klasik sosyal teori, kapitalizm, bürokrasi, otorite, yabancılaşma, anomi vb. gibi moderniteye ait meseleler yanında kitle iletişim araçlarını "marjinal bir görüngü" olarak değerlendirmiştir. ${ }^{5}$ 1950'li yıllar, gerçek televizyon çağının başladığ 1 yıllardı ${ }^{6}$ ve etkileri görmezden gelinemez bir hâl aldığı için kitle iletişim araçlarına ilgi duymaya başlayan sosyal teori için bu yıllar modernliğin sorgulandığı post-modernlik çağını ifade ediyordu. Dolayısıyla, sosyal bilimler, ilgi duymaya başladığı kitle iletişimini post-modern eğilimlerle inceleyip değerlendirecekti. Post-modern eğilim ise, sosyal bilimlerde "bilim"den "felsefe"ye, "gerçeklik"ten "dil"e, "teori”den "söylem”e doğru bir geçiş, bir kayma demekti. Sonuçta, iletişim bilimleri için bu talihsiz bir başlangıç, felsefe ile talihsiz bir ilk buluşma olacaktı.

\section{Sosyal Bilimler ve Felsefe: Ampirik ve Teorik Bir Nesne Olarak"Olgu"}

Sosyal bilimlerin konusu, en genel ölçülerde kabul edilen, en tarafsız nitelikteki ifadeyle, sosyal olgulardır, yani sadece toplum değil, toplumsal belirlenişe sahip olan, toplumsal olarak belirlenmiş her şeydir. Sosyal olgu, toplumsalın bilgisinin bölünebilir en küçük maddesidir ama tüm hakkında bilgi verir, tümü kapsayıcıdır. Mesele, tümü kapsayan bu temel birime nasıl yaklaşılacağı, nasıl ele alınacağına dairdir. Fa-

3 Steven H. Chaffe ve Charles R. Berger, “İletişim Bilimci Ne Yapar?”, Erol Mutlu (der. ve çev.), Kitle İletişim Kuramları, Ankara: Ütopya Yayınları, 2005, s.52.

4 John B. Thompson, Medya ve Modernite, çev., Serdar Öztürk, İstanbul: Kırmızı Yayınları, 2008, s.9.

5 Nick Stevenson, Medya Kültürleri: Sosyal Teori ve Kitle İletişimi, çev., Göze Orhon, Barış Engin Aksoy, Ankara: Ütopya Yayınlar1, 2008, s.13-15.

6 Jean-Noel Jeanneney, Başlangıcından Günümüze Medya Tarihi, çev., Esra Atuk, İstanbul: Yapı Kredi Yayınları, 2009, s.264. 
kat sosyal olgunun tanımlanmasının, sosyal bilimlerde hep epistemolojik bir güçlüğü olmuştur.

Doğa bilimlerindeki başat geleneğin pozitivist olması gibi, sosyal bilimlerin tarihsel gelişiminde de başat epistemolojik eğilim pozitivisttir. Pozitivist için bilimsel bilgi, doğruluk ve yanlışlıkları deney ve gözlem yoluyla sınanabilen, genel ve evrensel yasalar içinde geliştirilebilir. Sosyal olguların pozitivist açıklaması, ele alınan olgunun bir düzenliliğin örneği olduğunu ispattan ibarettir. Ele alınan olgu, bilinen belirli öncül koşulların (sebeplerin) gerçekleşmesi halinde, genel yasaların varlığı nedeniyle, beklenen belirli sonuçların ortaya çıkışı olarak açıklanmaktadır. Pozitivist için bilimsel bilginin objektif temelini sağlayan, sadece ve sadece deney ve gözlemdir. Dolayısıyla bilginin kaynağı da, sadece ve sadece deneyimlenebilir ve gözlemlenebilir olandir.

Pozitivizme en büyük ve radikal eleştiri (varoluşçuluktan anarşizme, dilbilimden yapıbozumculuğa dek pek çok akımda nüanslarla varlık gösteren) konvansiyonalist epistemolojiden geldi. Konvansiyonalizm, bilimde her türlü yasayı ve evrenselliği reddeder. Onlara göre bilimsel bilgilerin pek çoğu bilimcilerin kendi kurguları, kendi inşalarıdır. Başka bir deyişle, bilgiler neyin gerçek olduğunu belirlerler. Fakat konvansiyonalistler tam da bu noktada kararlı eleştiricisi oldukları pozitivistlerle aynı hizaya gelirler. Zira pozitivistlere göre de sosyal bilimcinin sosyal eyleme verdiği anlam ve onu tanımlamakta kullandığı kavram eylemin sahibininkinden (failinkinden) farkı olmamalıdır. Bu bakımdan, mesela, on dokuzuncu yüzyıl pozitivisti Herbert Spencer ile yirminci yüzyıl yapıbozumcusu Gille Deleuze, Marx’ın “yabancılaşma”, "yanlış bilinç" gibi kavramları kullanmış olmasının, onu, faillerin kendi eylemleri için kullandıkları açıklamaları sistematik olarak dışarıda bırakmaya -yani bir yanlışa- ittiği iddiasında birleşeceklerdir.

Hem pozitivist, hem de konvansiyonalist alternatifler karşısında realist bilim anlayışı ciddi bir seçenek olarak durmaktadır.7 Realiste göre nesnel gerçeklik diye bir şey elbette vardır; gerçeklik, bizim onlara ilişkin tasarımlarımızdan bağımsız olarak vardır. Dolayısıyla, bilimsel teori gerçekliği determine etmez, keşfeder. Sosyal bilimsel bilgi, toplumsal olanın betimlenmesidir, inşası değil. Bu onun konvansiyonalizmle ayrıldığı noktadır. Pozitivist görüşle ayrıldığı nokta ise bilimsel bilginin kuruluşuna ve amacına ilişkindir. Realiste göre bilimin önde gelen amacı, gözlenebilen ve deneyimlenebilen olguların ve olgular arasındaki düzenli ilişkilerin nedensel açılamasını yapabilmektir. Bu açıklamalar, nedensel süreçlerin temelinde yatan toplumsal yapılar, kurumlar ve ilişkilere dairdir ve teori de bu toplumsal yapı, kurum ve ilişkileri betimlemekle görevlidir. Bir sosyal olgunun araştırma nesnesi yapılmasındaki amaç budur.

Realist bakış, Karl Marx’ın açıklıkla ve sistematik biçimde kullandığı bilim anlayışıdır. "Marx'ı realist olarak almanın sonucu, onu ya hümanist ve felsefeci ya da pozitivist ve

7 Pozitivist, konvansiyonalist ve realist bilgi teorileri hakkında detaylı bilgi için şu kaynağa başvurulabilir: Russel Keat ve John Urry, Bilim Olarak Sosyal Teori, çev., Nilgün Çelebi, Ankara: İmge Kitabevi, 2001. 
bilimsel olarak görmekten birini seçmek durumunda kalmaktan kurtulmaktır." ${ }^{\text {An- }}$ cak, Karl Marx’ın sosyal teoride bir "klâsik" olarak taşıdığ 1 değer bugünün düşünce dünyası için şüpheli bir konudur. Sosyal teorinin köklü bir revizyona ihtiyaç duyduğu ve böyle bir revizyonun sosyolojinin temel referans çerçevelerini oluşturan yazarların çalışmalarıyla başlaması gerektiği inancı ${ }^{9}$ yaygındır bugün. Sosyal teorinin klâsiklerinin, St.Simon, Comte ve Durkheim gibi "kurucular" ile Weber, Simmel ve Parsons gibi "geliştiriciler”in statüleri, onların çalışmalarıyla ortaya konulmuş olan kavram, kuram ve özellikle da paradigmalar, günümüz sosyal teorisinin neredeyse asli konusudur. "Sosyoloji, 19. yüzyıl paradigmasının üzerine bir şey koyabildi mi? Yeni bir teori geliştirebildi mi?” Sosyal teorinin güncel akımları, bu ve benzeri soruların muhatabı olmaktadır. ${ }^{10}$ Marx’ın statüsü ise, sadece bugün değil, her zaman "tartışmalı" idi. ${ }^{11}$ Tom Bottomore'un "Marksizm ve Sosyoloji” başlıklı makalesine "Marksizmle sosyoloji arasında yüzyılı aşkın süredir yakın, huzursuz, çekişmeli bir ilişki devam etmekte” cümlesiyle başlamış olması ${ }^{12}$, Marx ile sosyoloji arasındaki temel ve karakteristik ilişkiyi tanımlaması bakımından önemlidir.

Marx’in yönteminin şüphe götürmez ölçüde bir sosyal bilim yöntemi örneği olmasına rağmen bu "bulanık", bu "huzursuz/çekişmeli" ilişkinin sebebi şudur: Marx, sadece Olmuş Olan'la değil, Henüz Geçekleşmemiş fakat Olmuş Olan'da içerilmekte olan Mümkün Gelecek’le de ${ }^{13}$ ilgilenmiş, bakışını geleceğe yöneltmiş bir toplumbilimciydi. Marx’ın sosyal teori içindeki ezeli tartışmalı konumu, sosyolojide dinamik bir modernlik teorisi oluşturma çabasının yarattığı gerilimin ürünüydü. Güncel şüphenin nedeni de, yine bununla bağlı olarak, onun bu geleceğe yönelmiş bakışının bir "toplum projesi” içerdiğine, böyle bir projeyi içermek suretiyle "modernliğin koyduğu hedeflerin kovalanmaya ve araçlarının da uygulanmaya değer" olduğunu kabul

8 Keat ve Urry, Bilim Olarak Sosyal Teori, s.114.

9 Anthony Giddens. Siyaset, Sosyoloji ve Toplumsal Teori, çev., Tuncay Birkan, İstanbul: Metis Yayınları, 2000, s.20-21.

10 Bu konuya özel iki çalışma: Margaret M. Poloma, Çağdaş Sosyoloji Kuramları, çev., Hayriye Erbaş, Ankara: Eos Yayınları, 2007; Stephen P. Turner (der.), Sosyal Teori ve Sosyoloji: Klâsikler ve Ötesi, çev., Ümit Tatlıcan, İstanbul: Küre Yayınları, 2008.

11 Daha 19. yüzyıl sonunda "Marksizm’in bilimsel durumu"nu tespit edebilmek için sarfedilen muazzam gayretler "devasa bir kaynakça" çıkartmıştı ortaya. 1900'de yapılan Uluslararası Sosyoloji Enstitüsü Kongresi, baştan sona "tarihi maddeciliğin” tartışılmasına hasredilmişti. 1918-25 döneminde, Marx’ın sosyolojisinin çeşitli temaları üzerine "gayet önemli” 500'ü aşkın eser yayımlanmış, Almanya’da sadece Marx-Engels Institute’a 192024 arasında Marksizm hakkında 70’ten fazla doktora tezi sunulmuştu. (Tom Bottomore ve Maximilien Rubel, Marx’in Sosyolojisi, çev., Zuhal Bilgin, İstanbul: Çiviyazıları Yayınları, 2006, s.69-79.) C. Wright Mills de, modern sosyal bilimlerdeki çalışmaların çok büyük bir bölümünün Marx’’n eserlerine karşı açılmış bir tartışma olduğuna dikkat çeker. (C. Wright Mills, Toplumbilimsel Düşün, çev., Ünsal Oskay, Ankara: Kültür Bakanlığı Yayınları, 1979, s.132.) Bu durumu Eric J. Hobsbawm, klasikler çağında toplumbilimin başlica konusunun, (toplumu devrimcileştirmek veya dönüştürmek bir yana) değişimin nasıl frenleneceği olmasına bağlıyor. İlerleyen dönemlerde de bunun toplumbilimin moda konusu haline geldiğini belirten Hobsbawm, toplumbilimin, günümüzde yirminci yüzyıl toplumbiliminin kurucu babası olarak adı sıkça Durkheim'la ve Weber'le anılan, fakat toplumbilimin tilmizlerinin bu etiketi her zaman kolaylıkla benimseyemediği Karl Marx'la ilişkisinin, bu yüzden bulanık olduğunu söylüyor. (Eric J. Hobsbawm, İmparatorluk Çağı 1875-1914, çev., Vedat Aslan, Ankara: Dost Kitabevi, 1999, s.296.)

12 Tom Bottomore, “Marxizm ve Sosyoloji”, Tom Bottomore ve Robert Nisbet (der.), Sosyolojik Çözümlemenin Tarihi, çev., Mete Tunçay ve Aydın Uğur, İstanbul: Verso Yayınları, 1990, s.34.

13 Ernst Bloch, Umut İlkesi, Cilt 1, çev., Tanıl Bora, İstanbul: İletişim Yayınları, 2007, s.246-247. 
ettiğine, dolayısıyla modernlikle aynı "suç"a ortaklık ettiğine ${ }^{14}$ dair post-modernist iddiaya sosyal teorinin de kendini inandırmış olmasıdır. Marx’ın sosyolojisine yönelik bugünkü şüphenin bir başka nedeni daha var ki sadece Marx’ı değil toptan sosyolojinin konumunu tehdit etmektedir. Güncel şüphe, "toplumsalın ve modernliğin sonu” tespitiyle sosyolojinin tümden işlevsizleştirilişiyle de alâkalıdır. Post-modernist düşüncenin artık sosyolojinin karşısında anlayabileceği bir "toplumsal”ın kalmadığı yönünde bir iddiası vardır. Bu iddiaya göre, modernliğin bilimi olan sosyoloji, onun iflası ve tükenişiyle birlikte tasfiye olmak durumundadır. Post-modern söylemin toplumun ve toplumsal olanın sonunu getirmesiyle artık sadece Marx'in değil, tümden sosyolojinin ölümü söz konusu edilmiştir.

Hiçbir şüpheye yer vermeksizin güvenle dile getirebiliriz ki, dünyayı yorumlamak değil değiştirmekle ilgilenen Marksçı eleştiri, temelden bir sosyal bilimdir. ${ }^{15}$ Zira, yine hiçbir şüpheye yer vermeksizin güvenle dile getirebiliriz ki, "Sosyal bilimin tamamı zorunlu olarak, toplumsal değişimin incelenmesidir. Başka bir konusu yoktur." ${ }^{16}$ Çünkü sosyal bilim, Pierre Bourdieu’nün kendi uğraşına verdiği isim gibi, "özgürlüğün bilimi"dir. ${ }^{17}$

Yirminci yüzyılın çok okunan toplumbilimcilerinden Maurice Duverger, alanın temel eserlerinden olan "Sosyal Bilimlere Giriş" kitabında sosyal bilimlerin amacının ne olduğunu tanımlarken, konu hakkında "giderilmesi güç ve ağır tartışmalara” saplanıp kalmamak için, sorunu "kökensel açıdan" ele almanın uygun olduğunu belirtir ve bu maksatla sosyal bilimlerin amacını onun tarihsel gelişmesinde bulup tespit etmeye yönelir. Duverger'in ilk tespiti, sosyal bilimlerin köklerinde, en genel olgu olarak mevcut haliyle toplumun kendisinin ne olduğu değil de ne olması gerektiği üzerinde durulmuş olduğu ve (bu maksatla da) olması gerekeni gösteren ilkeler ve kuralların saptanmış olduğu gerçeğidir. ${ }^{18}$ Yani sosyal bilimler, kökensel olarak, bir sosyal olgu bilimi değil, sosyal oluş bilimiydi. Toplumun ne olması gerektiğine odaklanan sosyal oluş perspektifi, Antik Yunan ve Aydınlanma düşüncesindeki kökleri itibarıyla bir sosyal felsefe idi. Bu felsefenin bilime doğru gelişmesinde rol oynayan şey de, "ideal bir sosyal örgütün ilkeleri üzerinde incelemede bulunabilmek için önce var olan sosyal örgütlerin incelenmesinin gerekliliği" idi. ${ }^{19}$ Bu nedenle sosyal bilimler, kökensel olarak, olguların gözlemi ile ilkelerin gözetilmesinden oluşan ikili bir yapıya sahiptir. Sosyal bilimlerin tarihi, bu sebeple, "filozofun tutumu ile gözlemcinin tutumu arasındaki, devamlı sayılabilecek nitelikteki, karşıtlık” üzerinde ilerlemiştir. ${ }^{20}$ Köklerini Platon'da bulup Rousseau ve Montesquieu’ye dek gelen birlik arayışı, esasında, ilkelerin alanı olan felsefe ile olguların alanı olan sosyoloji arasındaydı. Sosyoloji biliminin kurucusu ve isim babası A. Comte, biri olguya diğeri ilkeye vurgu yapan "düzen ve ilerleme" kavramları üzerine kurmuştu bilimini.

14 Zygmunt Bauman, Modernlik ve Müphemlik, çev., İsmail Türkmen, İstanbul: Ayrıntı Yayınları, 2003, s.336339.

15 C. Wright Mills, Marksistler, çev., T. Hasan, İstanbul: Ağaoğlu Yayınları, 1966, s.11-12.

16 Immanuel Wallerstein, Bildiğimiz Dünyanın Sonu, çev., Tuncay Birkan, İstanbul: Metis Yayınları, 2000, s.136.

17 Pierre Bourdieu, Toplumbilim Sorunları, çev., Işık Ergüden, İstanbul: Kesit Yayınları, 1997, s.80.

18 Maurice Duverger, Sosyal Bilimlere Giriş, çev., Ünsal Oskay, İstanbul: Bilgi Yayınevi, 1999, s.9.

19 Duverger, Sosyal Bilimlere Giriş, s.10.

20 Duverger, Sosyal Bilimlere Giriş, s.11. 
Felsefe ve sosyoloji ilişkisi, sosyal bilimlerin o denli temel bir meselesidir ki, alanın klasikleri arasında sayılan bazı isimler ve eserlerin teması tamamen buna ayrılmıştır. Birlik arayışının önemli bir ismi olan George Gurvitch, felsefe ile sosyoloji arasında yakın işbirliğinin zorunluluğunu dile getirmişti. Gerçekliğin ancak kavramsalın aracığıyla kavranabileceğine inanan Gurvitch’e göre, bir toplumsal meselenin analizindeki tutarlılığı, olguların açıklanma tarzını felsefi tutumla karşılaştırarak ölçmek mümkündü. ${ }^{21}$ Konunun bir başka önemli ismi Peter Winch ise felsefenin doğası hakkında net bir bakışa sahip olmak ile sosyal çalışmaların doğası hakkında net bir bakışa sahip olmanın sonunda aynı yere varacağını söylüyordu, çünkü toplumla ilgili her değerli çalışma doğal olarak felsefi bir nitelik taşıyacak ve her değerli felsefe de yine doğal olarak toplumla ilgili olacaktı. ${ }^{22}$

Gurvitch'in dikkat çektiği "olguların açıllanma tarzı" ile "felsefi tutum”, ya da Winch’in söyleyiş biçimiyle "değerli çalışma” ile "değerli felsefe”, aslında, sosyal bilimlerin kadim meselesi olan "ampirik gözlem” ile "teori” arasındaki ilişkiden söz etmektedir. Sosyal bilimlerin bilgi kaynağındaki temel birim, az önce de belirtildiği gibi, toplumsal olgudur. Bu sebeple, sosyal bilimler tarihinde ampirik gözlem ile teori hakkında kimi zaman öncelik kıyaslaması kimi zaman da uyum arayışı şeklinde süregelen tartışmalar, sosyal bilimlerin araştırma nesnesi olan olguların nasıl ele alınacağına ilişkindir.

$\mathrm{Bu}$ soru felsefenin bilgi teorisinden sosyal bilimlerin bilgi teorisine sirayet etmiş bir sorudur. Şayet takip etsek, ipin ucu elbette Antik Yunan düşüncesine kadar gider. Ama sosyal bilimler Aydınlanma düşüncesinin ürünü olduğundan, düğüm de esasen orada çözülmüştür aslında.

Aydınlanma düşüncesinin toplumsalın bilgisine dair motivasyonu, toplumun ne olduğu değil nasıl olması gerektiği yönündeydi ve bu da Cennet'i yeryüzüne indirme, Tanrı́nın öte dünya vaadini bu dünyada gerçekleştirme arzusundandı. Yeryüzünü insanlar için cennet kılma arzusu, insan aklını, gerçekliğin bilgisini ilahî semada değil, fâni dünyada aramaya yöneltmişti. Artık gerçekliğe dair bilgilerin kaynağı doxa değil, episteme idi. Bilginin kaynaklarındaki bu büyük devrim, Abelard, İbn Rüşd, Ockhamlı William, Dun Scotus ve Bruno gibi metafizikçiler tarafından hazırlanmış ve on altıncı yüzyıldan itibaren gerçekleşmeye başlamıştı. Fakat kesin bir devrim değildi bu. ${ }^{23}$ Tüm modern deneysel/bilimsel bilginin (epistemenin) gerçek atası Francis Bacon'dır. Onun gözünde, deneye dayalı bilim gerçek bilim ve dolayısıyla deneye dayalı bilgi de gerçek bilgidir. Öğretisine göre, deney duyularla olur ve duyular da yanılmazdır. Bütün bilgilerin kaynağını duyular oluşturur, somut dünyanın bilgisini duyular aracılığıyla ediniriz. Buraya kadar onu Rönesans veya Aydınlanmanın burjuva dünyasından ayıran önemli bir fark yoktur. Bilgi teorisinin modern felsefedeki

21 Kadir Cangızbay (der), Gurvitch: Sosyoloji ve Felsefe, Ankara: Ütopya Yayınları, 1999.

22 Peter Winch, Sosyal Bilim Düşüncesi ve Felsefe, çev., Ömer Demir, Ankara: Vadi Yayınları, 2007.

23 Yüzyıl başlarında, 1520^lerde, "İnsanlar ölüm anında evrensel ruhta değil, evrensel madde içinde çözünür" diyen İtalyan Pomponace'nin ders verdiği Padua üniversitesindeki anatomi derslerinde, profesörün teşrih masasında kesip biçtiği kişinin ruhu için aynı dersliğe konulmuş bir kürsüde de keşişin biri dua ediyordu. (Bkz. Ernst Bloch, Rönesans Felsefesi, çev., Hüsen Portakal, İstanbul: Cem Yayınevi, 2002, s.22.) 
başlıca iki dalı, rasyonalizm ile ampirizm, insan aklının bağımsızlığını ilan eder ve -tüm yanılsamalardan ve önyargılardan arınıp- onu kendinden ışık alarak dış dünyanın arı bilgisini elde etmeye yöneltir. Bacon’ın ampirizmi ise, dünyayı dönüştürmeyi hedefe koyarak, "bilgi üzerinde güç kurmayı" amaçlar. Bacon için, değişen doğayı ve tarihsel evrimin özel koşullarını tanımak ve tanımlamak söz konusu olduğunda, rasyonel "uygulanamayan", ampirik de "eksik" bir kriterdir. Böylelikle devrimci bir anlayış geliştirmiş olur Bacon. Bu anlayışta gerçeklik deneyimlenebilir olanla sınırlı değildir, henüz deneyimlenmemiş olan da gerçekliğe dâhildir. Gerçekliğin eksiksiz bilgisine erişmek isteyen akıl, deneyimlenmemiş olana da ilgi duymak zorundadır.

Bilginin bu materyalist yönelişinden itibaren, deneyimlenmiş olan, yani olgu, sadece ampirik obje olmaktan çıkıp teorik objeye dönüşmüştür. Başlangıcından itibaren "Ampirik çalışma mı teori mi?" tartışmasına girmiş ve halen çıkamamış gözüken sosyal bilimlere gereken de budur aslında. Böylelikle, bilimsel bilgi ile felsefi bilgi arasındaki farklılaşma da fonksiyonel bağlılıkla telafi edilmiştir. Sosyal bilimlerin olguların gözlemi ile ilkelerin gözetilmesinden oluşan ikili yapısının modern temelleri de bu şekilde atılmıştır. Sosyal bilimler teorisinin Comte sonrası kurucuları, Durkheim, Marx, Weber, Saint-Simon, Simmel (vb.), çalışmalarının felsefi bir temele dayandığını açıkça göstermekten kaçınmamışlardır.

Ne var ki, Rosenau'nun deyimiyle, sosyal bilimlerin başında bir "postmodernizm hayaleti” dolaşmaktadır bugün. Bu "hayalet”, sosyal bilimlerin epistemolojik kabullerini reddetmekte, metodolojik uzlaşımlarını çürütmekte, bilgi iddialarına direnmekte ve hakikatin her türlü versiyonunu bulanıklaştırmaktadır. ${ }^{24}$ Bütün bunların sonucunda postmodernizm, sosyal bilimlerin araştırma nesnesi olan 'olgu'yu, gerçeklik bağlarından kopartarak sadece teorik bir nesneye dönüştürmüştür. Çünkü, "toplum bilimlerinde katı hakikat iddialarında bulunmanın modası geçmiştir, ama teori ihtiyacı merkezi önemdedir". ${ }^{25}$

Demek ki, iletişim bilimleri ve felsefe ilişkisinde de, kitle iletişimini araştırmaya yönelik sosyal bilimsel girişim ve bu girişimin -kendi araştırma nesnesi olarak- iletişim olgusuyla ilişkisinin biçimleridir önemli olan.

\section{Bir "Olgu" Olarak İletişim}

İletişim çalışmalarının henüz yüzyılı aşmış tarihi, aslında düşüncenin iki binyıllık tarihinin kadim sorunlarından olan insan ve gerçeklik ilişkisine, başka bir deyişle, insanın gerçekliği algılama biçimlerine ilişkin sorunların taşıyıcısıdır. Gençleri yanıltıp yanlışa sevk edebileceği için "anlatıcılar” denilen kişileri siteden sürmeyi teklif eden toplumsalcı Sokrates’ten, anlatılanı değil anlaşılanı önemseyen performanscı Lyotard, Deleuze ve Derrida'ya kadar gelen çizgi, insanların gerçeklikle ilişki kurma biçimlerinde rol oynayan medyumlara ilişkin belli başlı birkaç yargının tarihidir.

24 Pauline Marie Rosenau, Post-Modernizm ve Toplum Bilimleri, çev., Tuncay Birkan, Ankara: Ark Yayınevi, 1998, s.21.

25 Rosenau, Post-Modernizm ve Toplum Bilimleri, s.152. 
İletişim çalışmalarının kısa sayılabilecek tarihi elbette farklı biçimlerde de tasnif edilebilir ama Nick Stevenson'ın bu hususta belirlediği "üç paradigma” bizim için açıklayıcıdır. Birincisi, "izleyici araştırmaları” olarak anılan çalışmalarla oluşmuştur. İkinci paradigma, en bilinen örneğini Frankfurt Okulu ile İngiliz ve Amerikan Marksizmi’nin oluşturduğu, eleştirel yaklaşım olarak da anılan, "ekonomi politik" bakıştır. Paradigmaların üçüncüsü ise, kültürel pratikleri açıklama çabasıyla postmodernizm etrafında ayırt edilebilir bir düşünsel alan kurmuş olan, "anlam ve söylem analizi”ne yönelmiş çalışmalardır. ${ }^{26}$ Graham Murdock da iletişim çalışmalarının teorik sorunlarından söz ederken bu üç paradigmaya denk gelen üç epistemoloji belirler: Ampirizm, gerçekçilik, yorumlama. ${ }^{27}$ Stevenson'ın bu üç paradigması ve Murdock'in üç epistemolojisi, bizim burada altını çizdiğimiz üç bilim anlayışının iletişim çalışmaları alanındaki temsilcileridirler. İzleyici araştırmaları ve ampirizm, pozitivizmi temsil eder; ekonomi politik bakış ve gerçekçilik, eleştirel sosyolojik yaklaşımı; söylem analizi ve yorumlama da konvansiyonel yaklaşımı. Stevenson, "sunulan üç paradigma arasında bir seçim yapmak zorunda" olmadığımızı, zira tartışılan araştırmacıların çoğunun "mevcut farklı yaklaşımların en az iki tanesini bir araya getirmekte" olduğunu söyler. ${ }^{28}$ Doğal olarak, bilim anlayışları için de aynı şeyi söylememiz gerekiyor, o konuda da iletişim araştırmacılarından bazıları zaman zaman farklı iki anlayışı bir araya getirmiştir. Örneğin, toplumsal evreni incelerken politik ya da ahlâksal her tür düşünceden kopup sadece gerçekliği ölçmenin araçlarını bulup kullanmayı benimserken pozitivist ve fakat kavramları belirgin biçimde bir toplumsal eylem bilimine çekerken de sosyolojist Lazarsfeld, ya da iletişimi egemenlik ilişkilerinin kültürel bir biçimi olarak ele alıp medyatik kültürün kullanımı ile güç ilişkilerini yeni bir kuramsal çözümde bir araya getirirken sosyolog ve fakat medyatik iletilerin üretim anıyla alımlama anını birbirinden kopartırken ("incoding/decoding”) konvansiyonalist Stuart Hall gibi.

İletişim denilen toplumsal süreç, birçok disiplinin kesiştiği noktada yer alır. Bu sebeple, sosyoloji, felsefe, tarih, coğrafya, psikoloji, siyasal bilimler, etnoloji, ekonomi gibi sosyal bilimlerin farklı kollarının ilgisini çekmiştir. Kendini geliştirme aşamasında olan her disiplinin yaşadığı bilimsel meşruluk sorunu, sosyal bilimler içerisinde kendine yol arayan iletişim bilimlerinin de temel bir sorunu olmuştur; bilimsel meşruluk, sosyal bilimlerin bu özel alanının kuruluşu sırasında da onu meşgul etmiştir. "Bu durum onu, doğa bilimlerine ait ve benzerliklerden uyarlanmış şemalar1 benimseyerek, bilimsellik kazandıran modeller aramaya yöneltmiştir." ${ }^{29}$ İletişim bilimleri literatürünün oluşmaya başladığı ilk evre, "pozitivistik bir toplum bilimi pratiği tarafından" biçimlendirilmişti. ${ }^{30} \mathrm{Bu}$ da demek oluyor ki sosyal bilimlerdeki

26 Stevenson, Medya Kültürleri: Sosyal Teori ve Kitle İletişimi, s.19.

27 Graham Murdock, İletişim, Modernlik ve İnsan Bilimleri, Mehmet Küçük (der. ve çev.), Medya, İktidar, İdeoloji, Ankara: Ark Yayınevi, 1994, s.373.

28 Stevenson, Medya Kültürleri: Sosyal Teori ve Kitle İletişimi, s.346.

29 Armand Mattelart ve Michèle Mattelart, İletişim Kuramları Tarihi, çev., Merih Zıllıŏ̆lu, İstanbul: İletişim Yayınları, 2006, s.7.

30 Hanno Hardt, Eleştirelin Geri Dönüşü ve Radikal Muhalefetin Meydan Okuyuşu: Eleştirel Teori, Kültürel Çalışmalar ve Amerikan Kitle İletişim Araştırması, Mehmet Küçük (der. ve çev.), Medya, İktidar, İdeoloji, Ankara: Ark Yayınevi, 1994, s.1. 
başat geleneğin pozitivist olması gibi, iletişim bilimlerinin tarihsel gelişiminde de başat epistemolojik eğilim pozitivisttir.

İletişim çalışmalarının, modernliği tanımlamaya çalışırken gazeteleri de konu edinen ilk sosyologların araştırmalarıyla başlatılan tarihi, aynı zamanda, iletişim bilimlerinde pozitivizmin de başlangıç tarihidir. Genel olarak Alexis de Tocqueville'in 1835'te Fransa ve Amerika'da gazeteleri sayı, içerik ve biçim açısından karşılaştırmalı olarak incelediği ve aforizmaya yaklaşan o ünlü "Gazetelerin etkilerini ortadan kaldırmanın tek yolu, sayılarını artırmaktır” sözünü kendisine söyleten sonuçlara vardığı çalışmasıyla başlatılan bu tarih, istatiksel verilerin desteğiyle (medyatik haberlerin yoğunluğuna bağlı olarak intihar vakalarının artmadığını ortaya koyarak), gazetelerin bireysel bilinçlere doğrudan etkisi olduğu görüşünü çürüten Emile Durkheim'in “İntihar”(1897) adlı eseriyle ilerler. İletişim araştırmalarının pozitivist tarihi içinde, modern dünyanın geçmişten devraldığ men insan/bağımlı insan arasındaki eşitsizlikçi ilişkinin yeniden üretiminde iletişimin oynadığı rolü sosyal bilimler içinde ilk fark edenlerden olan Thorstein Veblen de $^{31}$ vardır, Max Weber'in 1910 yılında Alman Sosyoloji Derneği için hazırladı̆̆g, medya üzerine bütüncül bir program oluşturan, orada ele alınmasını istediği soruların bugün halen geçerli olduğ $\mathrm{u}^{32}$ ve bu yönüyle adeta "medya sosyolojisi”ne giriş niteliğindeki yedi sayfalık raporu da. Weber'in kapsamlı önerisi, edilgin izleyicilerin karşı karşıya kaldığı etkiyi tanımlamak için ünlü "şırınga” ya da "derialtı iğne” ("hypodermic needle") deyimi ile medya üzerine araştırma alanının sınırlarını belirlemek için "mass communication" deyimini bulan Harold Laswell'in Birinci Dünya Savaşı́ndaki propaganda tekniklerini çözümleyen çalışmasıyla (1927) uygulanır hale gelir gibi olmuştu. ABD Ordu Araştırma Birimi adına silahlı kuvvetlere yeni kaydolanlar için hazırlanmış oryantasyon filmlerinin ikna etme gücünü araştıran Carl Hovland'ın veya W.W.Chartes'ın 1930'ların başında yürüttüğü ve film izlemiş olmanın “ölçülebilir” tutum değişikliği yarattığını saptayarak "filmlerin güçlü bir eğitim aracı oldukları” sonucunu ortaya çıkaran ${ }^{33}$ öncü çalışmaları da özgün bir disiplin olarak iletişim bilimlerinin hazırlayıcısı olan pozitivist hamlelerdir. ${ }^{34}$

Paul Felix Lazarsfeld'in medya ve izleyicilere yönelik ampirik çalışması, bunların bir devamı olarak anılsa da, onunki bu öncü çalışmalardan kesin bir kopuş ortaya koyar. İki sebeple: Birincisi, basit bir pozitivist ölçme işleminin ötesine uzanan çalışmalardır bunlar. Mantıksal pozitivizmin kaynağından, Albert Einstein'in etkisindeki Viyana çevresinden 1935'te Amerika sürgününe zorlanan bu Avusturyalı sosyolog, pozitivizmle olan bağı gereği doğal olarak "gerçekte medya üzerine süregelen önyargıları ve medya konusunda çok yaygın düşünce yöntemlerini sorgulamaya götüren inançların taşıyıcısıdır" ${ }^{35}$ Tümüyle kavramsal ve kurgusal bir tartışmanın yerine

31 Ünsal Oskay, 19. Yüzyıldan Günümüze Kitle İletişiminin Kültürel İşlevleri, İstanbul: Der Yayınları, 1993, s.1823.

32 Lang, İletişim Araştırmaları: Kökenleri ve Gelişmesi, s.31.

33 Lang, İletişim Araştırmaları: Kökenleri ve Gelişmesi, s.34-35.

$34 \mathrm{Bu}$ noktada, Chicago Okulu ve Robert Park’ın "göçmenlerin gazete okuma alışkanlığı ve modernizm" meselesini ele alan, etnografi yönteminin kullanıldığı çalışmaların da hatırlanması gerekir. Chicago Okulu ve Robert Park’a, makalenin ilerleyen bölümlerinde farklı bir bağlamda değinilecektir.

35 Éric Maigret, Medya ve İletişim Sosyolojisi, çev., Halime Yücel, İstanbul: İletişim Yayınları, 2011, s.97-98. 
Lazarsfeld, bilgi ve veri toplamaya, iletişimsel eylemlerin çözümlemesine yönelir. Fakat Lazarsfeld'in kavramlardan ziyade alan araştırmasına yönelen ampirizmi, bu kavramları belirgin biçimde bir toplumsal eylem bilimine çeker. "Lazarsfeld, sınırlı pratik amaçlar doğrultusundaki araştırmalara kendini iyice vermiş olmakla birlikte, daha genel konulara da gözünü kapamış değildi." ${ }^{36}$ Bu bakımdan Lazarsfeld'in çalışmaları olgunlaşma aşamasındaki sosyolojik yaklaşımın da bir örneğidir. İkincisi de, artık, sosyal bilimler değil, uzmanlaşmış bir disiplin olarak iletişim bilimleri alanında yapılmış çalışmalardır onunkiler.

Sosyal bilimlere ait bir alan olduğu için, bu pozitivist başlangıca iletişim bilimleri içinden bir tepki de gecikmemiştir. İletişim bilimlerindeki konvansiyonalizm de, aynı şekilde, pozitivizme tepkiden doğmuştu. ${ }^{37}$ Gerçeklik, gerçeklik üzerine söylemden başka bir şey değildir inancındaki konvansiyonalist yaklaşım, iletişim çalışmaların "anlam" ve "söylem" analizlerine doğru yönlendirdi. Konvansiyonalist espistemoloji, iletişim bilimlerindeki hâkimiyetini yapısalcı yöntem aracıllğıyla kurmuştur. "Tomurcuklanan her bilim, ilk olarak yöntemlerini belirlemeye çalışır."38 İletişim bilimleri de aynı jesti tekrarladı. Yöntem olarak dilbilim ve antropolojinin bilim dünyasına sunduğu yapısalcıllğı benimsedi.

Günümüzde göstergebilimden psikolojiye, antropolojiden estetiğe kadar sosyal bilimlerin her alanda çok sayıda tanım, anlatım, uygulama ve örneği olan yapısalcı yöntem on dokuz ve yirminci yüzyıl sosyal bilimlerinde yapı kavramı birçok önemli ve değişik bakış açısından ele alınmışsa da, Antik Yunan'dan modern düşüncedeki görünümlerine kadar hepsinin kökeninde, şu ya da bu şekilde, gerçekliğe ilişkin "modeller" bulma amacı yatmaktadır. ${ }^{39}$ Yapısalcılık, bir dünya görüşü olmaktan öte, kendine özgü analiz mantığı olan bir araştırma yöntem ve tekniğidir. Sosyal bilimlere ait alt dalların, yirminci yüzyıl düşünce ve bilim dünyasında kendi özgün konumuna erişmesi, her birinin kendine özgü bulgu ve birikiminin yanı sıra, bir yöntem olarak yapısalcılığın benimsenmesiyle doğru orantılıdır. Yapısalcılık, dilbilimin de etkisiyle, antropolojide veya psikanalizde açıkça gözlenebileceği gibi, girdiği bütün alanlara özerk bir bilim dalı olarak sistematikleşme olanağı sunmuş, ya da en azından bu süreci hızlandırmıştır. Ne var ki, yapısalcılığın sosyal bilimlere nüfuz etme ve yönlendirme biçimi, sosyal bilimlere metodolojide kısmi bir ilerleme sağlamışsa da, nihayetinde, araştırma nesnesini kapalı devre bir analizle sınırlandırmış, nüfuz ettiği alanı kalıcı ve kanıksatıcı bir muhafazakârlıkla kuşatmıştır. Terry Eagleton, bunu, yapısalcılığın bir "tin teokrasisi olarak davranma tarzı"na sahip olmasına bağlıyor. "Özenli kodlamaları, evrensel şemaları ve çıkarcı indirgemeciliğiyle yapısalcılık" Eagleton’a göre, "gerçeklikte zaten belirgin olan bir şeyleşmeyi" kültür ve ideoloji alanın-

36 Lang, İletişim Araştırmaları: Kökenleri ve Gelişmesi, s.37.

37 Pozitivizm, zaten tepki duyulacak bir şeydi. Engels’in deyimiyle, "ölümsüz doğruluklar" söz konusu olduğunda, işler, toplumsal bilimlerde "daha da kötü gider." (Friedrich Engels, Anti-Dühring, çev., Kenan Somer, Ankara: Sol Yayınları, 1977, s.170.) Zira, "doğa ve insan dünyası ilkelere uymaz, ilkeler ancak doğa ve tarihe uydukları ölçüde doğrudur."(Engels, Anti-Dühring, s.92.)

38 Julien Freund, "Max Weber Zamanında Alman Sosyolojisi", Tom Bottomore ve Robert Nisbet (der.), Sosyolojik Çözümlemenin Tarihi, Çev. Mete Tunçay ve Aydın Uğur. Ankara: Verso Yayınları, 1990, s.180.

39 Tom Bottomore ve Robert Nisbet. "Yapisalc1lık". Bottomore, Tom ve Robert Nisbet (der.), Sosyolojik Çözümlemenin Tarihi. Çev. Mete Tunçay ve Aydın Uğur. Ankara: Verso Yayınları, 1990. 
da yeniden üretiyordu. Yapısalcılık, bu anlamda, "eşanlı olarak radikal ve muhafazakâr"dı, "modern kapitalizmin stratejileriyle suç ortaklığı" yapıyordu. Yapısalcılık "bireyleri yalnızca gayri kişisel kodların boş mevzileri olarak ele alırken, modern toplumun gerçekte bireylere çektiği muameleyi (ama öyle yapmadığını iddia ettiği bir muamele) taklit ediyor ve böylelikle modern toplumun ideallerinin maskesini düşürürken mantığını onaylıyordu." ${ }^{40}$

Kültürel çalışmaların Raymond Williams, Richard Hoggart ve Stuart Hall ile temsil edilen ilk döneminin ya da Roland Barthes'ın ayrıcalığı bir yana, yapısalcılık, gerçekten de kitle iletişim çalışmalarının bilimsel statüsüne ilk adımda katkıda bulunduysa $\mathrm{da}$, sonrasında onu sosyolojik bir teori geliştirebilme yolundan alıkoydu. Bunun en önemli iki sebebi, yapısalcı yöntemin (1) tarihsel ve toplumsal koşul ve belirlenimler, yani kısaca gerçeklik yerine, anlam'a, yani o koşulların ürünü olarak dişa vurulmuş olana yönelmesi, dışa vurulanı incelemeyi tercih edişi ve (2) gerçeklik ile bireyin gerçeklik yanılgısı arasındaki ilişkiyi kitle iletişım araçları tarafından üretilip taşınan "sembolik" bir ilişki olduğu inancını taşıyor oluşudur.

İletişim çalışmaları, ağırlıklı olarak “anlam üretimi” ve "temsiller” konusuna bu vesileyle odaklandı, medyanın ideolojik rolü üzerinde durarak, "anlam” taşıyıcılar1 ve "temsil” olarak metin, mesaj, gösterge, kod vb.'nin dilsel yapısına yoğunlaştı. Şüphesiz burada Batı Marksizminin "maddi dünya"nın yanında "zihinsel dünya”ya ilgi duymuş olması, bu çerçevede Althusser ve Gramsci gibi temsilcileri aracılığıyla ideoloji çözümlemelerine yönelmiş olmasının da etkisi vardır. Sonuç tartışılmazdır: "İletişim kuramları tarihinde bir semiyolojik dönem olmuştur." ${ }^{11}$ Yapısalcılığın (Sausurre, Levi-Strauss, Mauss, Barthes) etkili olduğu bu dönem, yapibozumculuğun (Lyotard, Baudrillard, Foucault, Derrida) etkili olduğu postmodernist akımın hâkimiyetiyle kalıcılaşmıştır.

Postmodernist jargonda toplumsal olgular ve ilişkiler dil tarafından oluşturulur, hatta "toplum basitçe dil gibi değildir, dil'dir" ${ }^{42}$ ve bu yüzden hakikatin söylem dışında hiçbir dişsal bilgi referansı yoktur. Gelgelelim; "Felsefe problemlerinin dünyanın değil, dilin içinden çıktığını söyleyemeyiz." ${ }^{43}$ Felsefe problemleri, dil değil dünya kaynaklıdır. O yüzden, felsefi problemlerin çözümü dilde değil dünyada aranmalıdır. Ya da, Marx’ın uyarısını izlersek, mantığın nesneleri ile nesnelerin mantığı birbirinden ayrılmalıdır. Aksi halde felsefe, gerçekte, gerçek hiçbir sorunu yanıtlamaz, onların yerine büsbütün başka sorunları geçirir, "gerçek sorunu kurgusal sorun biçimine" dönüştürür. ${ }^{44}$

Toplumdaki gerçek yaşam, felsefeye kavram ve kurgu gereği sokuşturulacak bir şey değil, felsefenin mantıksal kurulumunun merkezi olmalıdır. Ama nesnel bir gerçek-

40 Terry Eagleton, Postmodernizmin Yanılsamaları, çev., Mehmet Küçük, İstanbul: Ayrıntı Yayınları, 1999, s.154155.

41 Maigret, Medya ve İletişim Sosyolojisi, s.159.

42 Ellen Meiksins Wood, “Postmodern Gündem Nedir?", Ellen Meiksins Wood ve John Bellamy Foster (der), Marksizm ve Postmodern Gündem, çev., Ahmet Fethi, Ankara: Ütopya Yayınları, 2001, s.12.

43 Winch, Sosyal Bilim Düşüncesi ve Felsefe, s.26.

44 Karl Marx, "Mutlak Eleştirel Eleştiri”, Karl Marx ve Friedrich Engels, Kutsal Aile, çev., Kenan Somer, Ankara: Sol Yayınları, 2003, s.125. 
liğin varlığını veya akılcı araçlarla kabul edilmiş bir gerçeklik anlayışını reddeden radikal görecelik anlayışı ve modernliğin vaatlerine yönelik inkârcı entelektüel stratejisiyle sosyal bilimlerde söylemsel bir hâkimiyet kurmuş olan postmodernizmin uzun sayılabilecek bir dönemdir mevcut durum ve konumu bu.

Hem artık söz konusu olan felsefe de değildir: Jameson’a göre, felsefenin yerini bugün teori denilen yeni bir şey almıştır ve bu da kesinlikle postmodernizmin görünümleri arasında kabul edilmesi gereken "açımlama sapkınlığı" denilebilecek bir durum neticesinde gerçekleşmiştir. Bu ikame sürecinde birkaç “an”dan söz eder Jameson: Öncelikle, kavramların içyapısının, daha doğrusu iç boşluğunun ya da çatlaklarının keşfedildiği bir ilk an vardır. İkinci an'da bu keşif, felsefi bir soruna, kavramın ikilemleri ve başarısızlıkları sorununa dönüşür; bu anda teori, kendisini "henüz hiç kimsenin bütünüyle dolaşmadığı, bazılarının (belki) kulelerinden geçici olarak baktığı, bazılarının da yeraltı sığınaklarının kısmi haritasını çıkardığı dev boyutlu bir yapı" gibi sunar. Nihayet üçüncü ân’a gelindiğinde, çözülebilecek bir sorun, önceki kavramların şimdi yeniden biçimlendirildiği yepyeni bir teorik kodlama sistemi içinde kaybolarak, bir çözüme kavuşmadan ertelenir. Bir tür "dil polisliği” yapan teori, ideolojik imaları hedef alan şaşmaz bir arama ve yok etme misyonu ile hareket etmektedir ve sonuçta eleştiri de artık "belli sözcük ve terimlerin düşürdüğü uzun gölgenin, en kusursuz tanımların ürettiği tartışmalı dünya görüşlerinin, görünürde sımsıkı kapalı önermelerin dışarı sızdırdığı ideolojilerin, haklı argümanların en sakıngan hareketlerinin bıraktığı gözle görülür hata izlerinin keşfedilmesi” haline gelmiştir. ${ }^{45}$

Konvansiyonalist bakış sosyolojiden pozitivizmi anladığı için iletişim bilimlerini sosyolojik bakıştan uzaklaştırmış, "teori için teori" çizgisine getirmişti. Mesela, Barthes, Eco ve Foucault için medya alanı, toplumsal gerçekliğin egemenlerin yararına anlamlar üretimi yoluyla olağanlaştırılıp istikrarlı hale getirildiği bir alandı ve sosyoloji sadece bununla uyumlu bir pratik olabilirdi. Dolayısıyla onlar, medyanın güç ilişkilerini yansıtan bilişsel yolları, dil, gösterge ve söylem analizleriyle ortaya çıkarmanın peșindeydiler. ${ }^{46}$ Hâlbuki anlam üretimi sorunu, dili insan ilişkilerinin modeli değil, yalnızca insan ilişkilerinin bir öğesi olarak ele alan sosyolojik bir bakışla ele alınmalıydı. Pierre Bourdieu'nün başardığı şey buydu. $\mathrm{O}$, anlam üretim ve tüketimini, bunlardaki yönelimi "toplumsal konumlar"a bağlamıştı; anlamı kodlayan da çözen de "toplumsal alan"dı, başkası değil.

Hem pozitivist, hem de konvansiyonalist alternatifler karşısında, realist bilim anlayı-

45 Fredric Jameson, Modernizm İdeolojisi, çev., Kemal Atakay, Tuncay Birkan, İstanbul: Metis Yayınları, 2008, s.397-400.

46 Bu nedenle, kimi zaman, gerçekte konvansiyonalist bakışın Adorno’cu, Marcuse’ci bir tutumu temel aldığı da söylenmektedir, zira bu bakış açısına göre de "aydın, evreni anlayabilecek ve burjuva sınıfının kültür endüstrileri üzerindeki egemenliğinin yapı-bozumunu gerçekleștirecek tek kişidir.” (Maigret, Medya ve İletişim Sosyolojisi, s.25). Fakat bu yanlış bir yorumdur. Adorno ve Eleştirel Teori kitleler hakkında karamsar bir tutum sergilemiştir belki ama nihilizme asla varmamıştır. Fransız kültürel pratikler sosyolojisi, mesela Michelle de Certeau ve Pierre Bourdieu de kitlelerin kitle iletişimi denilen bu büyük sessizlikte -neden olmasın- söz alabileceklerini, bunun nasıl gerçekleşeceğini, imkânlarını göz önüne serdiler. Bu yaklaşım tarzı, Raymond Williams'ın yanı sıra Cultural Studies içinde Stuart Hall ve David Morley'in eleştirel tutumla ampirizmin bir bireşimini oluşturan çalışmaları aracılığıyla daha liberal bir çizgiye taşınmıştır. 
şı, başka bir deyimle eleştirel sosyolojik anlayış ciddi bir seçenek olarak durmaktadır. Realiste göre nesnel gerçeklik diye bir şey elbette vardır; gerçeklik, bizim onlara ilişkin tasarımlarımızdan bağımsız olarak vardır. Dolayısıyla, bilimsel teori gerçekliği determine etmez, keşfeder. Sosyal bilimsel bilgi, toplumsal olanın betimlenmesidir, inşası değil. Bu onun konvansiyonalizmle ayrıldığı noktadır. Pozitivist görüşle ayrıldığ 1 nokta ise bilimsel bilginin kuruluşuna ve amacına ilişkindir. Sosyolojik anlayışa göre bilimin önde gelen amacı, gözlenebilen ve deneyimlenebilen olguların, yani Olmuş Olanın ve onlar arasındaki düzenli ilişkilerin nedensel açıklamasını yapabilmektir. $\mathrm{Bu}$ açıklamalar, nedensel süreçlerin temelinde yatan toplumsal yapılar, kurumlar ve ilişkilere dairdir ve teori de bu toplumsal yapı, kurum ve ilişkileri betimlemekle görevlidir. Bir sosyal olgunun araştırma nesnesi yapılmasındaki amaç budur.

Eleştirel sosyolojide sosyal olgular diğer sosyal olgular yardımıyla açıklanır. Örneğin, sosyal davranış kavramının açıklığa kavuşturulma isteği, tamamen, sosyal davranışın neler tarafından ve nasıl üretildiği sorusunun araştırılmasına yönelik bir taleptir. Anlam da bir sosyal olgudur, dolayısıyla, başka sosyal olgularla ilişkisi içinde kavranabilir. Anlamın yapısını gerçekliğin bilgisi karşısında fetişleştiren şey, anlam ile toplumsal olanın birbirinden aşırı derecede farklılaştırılmasıdır, dil ve söylem analizleri bu yüzden sorunludur. Bu tür bakış açısının atası olan Durkheim’den beri böyle bir sorunu var sosyal bilimlerin. $\mathrm{O}$ da mesela intihar, din ve işbölümü olgularını izah ederken, ölçüt koyma ve referans bulma konusunda farkı sosyal olgulara başvurmaktan kaçınmış olmanın bütün gerilimini yaşamıştır.

İletişim bilimleri bu anlayışa ilk kez, politik Marksizm'den ve onun politik pratiklerinden yapısal olarak kopmuş akademik entelektüeller tarafından yönlendirilen "Batı Marksizmi"nin ${ }^{47}$ bir temsilcisi olan Frankfurt Okulu ile yakınlaştı. 1923'te kurulan Frankfurt Toplumsal Araştırmalar enstitüsü, toplumsal incelemede felsefi yapı ile ampirik araştırmanın yan yana olmasını önemsiyordu. ${ }^{48}$ Leo Löwenthal'in popüler dergilerde biyografisi yayınlanan kişilerin meslekleri ve başarı hikâyelerinde görülen 1910’lu yıllar ile 1940’lı yıllar arasındaki belirgin değişmeyi (ilk dönemdeki “üretim kahramanları"nın yerini ikinci dönemde "tüketim kahramanları"nın alışını) çarpıcı biçimde göstererek, kitle iletişim araçlarının içeriklerindeki değişimin toplumlardaki daha geniş alanlara yayılan, daha derin değişikliklerin sonucu olduğunu ortaya koyan çalışması, bunun çok tipik bir örneğidir. Aynı şekilde, Adorno'nun "Otoriteryen Kişilik” araştırması da (1950) ${ }^{49}$, bugüne dek çok sayıda eleştiri (özellikle soruların sorulma biçimleri hakkında eleştiriler) almış olmakla birlikte, otoriteryen kişiliğin karakter özelliklerine sosyolojik boyutlar getirmiş olmasıyla öncü bir çalışma olarak değerini korumaktadır. Otoriter söylem ve antidemokratik propagandaya açık kişiyi işaret eden "otoriteryen kişilik" iki olgu arasındaki kesişmeye göndermede bulunur:

47 Perry Anderson, Bati'da Sol Düşünce, çev., Bülent Aksoy, İstanbul: Birikim Yayınları, 1982, s.49.

48 Alex Callinicos, Toplum Kuramı, çev., Yasemin Tezgiden, İstanbul: İletişim Yayınları 2004, s.365.

49 Enstitü’nün Nazi Almanya’sını terk ederek ABD’ye yerleşen üyeleri, burada Amerikalı meslektaşlarıyla birlikte, ana konusu başlangıçta antisemitizm olarak belirlenen fakat giderek etnosantrizm ve politik/ekonomik tutuculuğu içine alarak genişleyen "Önyargı Üstüne Çalışmalar” genel başlığı altında beş ciltlik bir araştırmaya imza atarlar. İkinci Dünya Savaşı’nın hemen sonrasında yapılmış bu araştırmanın üçüncü cildi “Otoriteryen Kişilik” adını taşır ve -Amerikalı diğer üç yazarın imzasıyla birlikte yayımlanmış olmasına rağmen- daha çok Theodor W. Adorno'nun yazdığı bölümle tanınır. 
Kişinin kendisini güç gereksinmesi içinde hissetmesine yol açan psikolojik süreç ve bu gereksinmeleri karşılayan toplumsal süreç. Burada iki olgu da birbirinden bağımsız değildir ve çalışmanın da ortaya koyduğu üzere, psikolojik süreç tarihsel ve toplumsal şartlardan etkilendiği gibi toplumsal süreç de psikolojik süreçten beslenmektedir. ${ }^{50}$

Eleştirel paradigmanın en anlamlı çıkışı, anlam ve ideolojiyi toplumsala yayıp, en sıradan toplumsal ilişkide dahi o anlamı ve ideolojiyi görebilmesiydi. Bu yaklaşımı hiçbir düzeltme ve ilave yapmaksızın, olduğu gibi Frankfurt Okulu'na bağlayabiliriz. Ama eleştirel paradigmanın diğer ucunda duran Kültürel Çalışmalar söz konusu olduğunda, onların ideolojiyi ve iktidarı daha kısıtlı bir alanda, ileti ve izleyici arasındaki ilişkide ele aldıklarını söylemek gerekir. ${ }^{51}$

Kültürel Çalışmalar’ın Richard Hoggart, Raymond Williams, Stuart Hall ve David Morley tarafından temsil edilen, egemenlik altındaki toplumsal kesimlerin güç ile ilişkisinde kitle iletişim araçlarının rolüne odaklandığ erken evresi ile popüler kültür ve kitle kültürüne yeniden saygınlık kazandıran, media studies, film studies, gender studies, gay ve queer studies vs. gibi, öncüllerinin her zaman sahip çıkmadığı konular ve uygulamaların -bilhassa Amerikan ve Fransız üniversitelerinden- yayıldı̆̆ geç evresi arasında bir ayrım yapmak her zaman gerekmiştir. Postyapısalcılık ve yapıbozumculuk gibi kuramların etkisine girmiş olan bu eğilimin kültür eleştirisindeki etkisinin "amaçlılığın intiharı" olduğunu söyleyen Eagleton, bu durumun düşünceyi ve eleştiriyi poplaştırarak müthiş bir depolitizasyon döngüsü kurmuş olduğunu dile getirir. Çalışandan ziyade çiftleşen bedenlere odaklanmış poplaşmış akademik faaliyet, lateks edebiyatı, kopçalı pantolon askısının tarihi ve göbek piercinginin siyasal anlamları üzerine yoğunlaşmaktadır artık. Eagleton, popüler ve gündelik olana yönelen kültür kuramının, entelektüel akıl ile gündelik hayat arasında bir 'devaml1lık ilişkisi' kurmuş olmasını takdirle karşılar, ama sonuçta kurduğu o depolitizasyon döngüsü sebebiyle eleştiriyi kanıksatıcı bir muhafazakârlıkla kuşatmış olduğuna da dikkat çeker. Popüler konuları gündelik varoluşun en sıradan ayrıntılarına kadar teorize eden kültür kuramının, var olanın değişimi hakkında toplumsal herhangi bir öneride bulunmadığını hatırlatır. ${ }^{52}$ İngiliz cultural studies'in erken evresine denk gelen bir tarihsel dönemde bütün bilimsel faaliyetini toplumsallık vurgusuna bağlayan,

50 Theodor W. Adorno, Otoritaryen Kişilik Üstüne, çev., Doğan Şahiner, İstanbul: Say Yayınları, 2011.

51 Oysa, modern kitle toplumunda ideoloji ve iktidar, yalnızca bu ilişkide değil, en sıradan, en gündelik, en evcil ilişkilerde kendini gösterir, ve zaten medyanın izleyici kitle üzerindeki ideolojik etkisi de buralarda hazırlanan zemin üzerinde yükselir. İspat ve ikna için, bu konuda üretilmiş külliyatın uzun referanslarla bir dökümünü yapmaktansa, Adorno, Horkheimer, Marcuse ve Benjamin'in bu yöndeki teorik çabasını saygıyla anmak ve Mills’ın, kitle toplumu çağında medya araştırmalarına yönelik şu uyarısını hatırlatmakla yetinelim: "On sekizinci ve on dokuzuncu yüzyıldaki 'kamu' yerine, yirminci yüzyılla birlikte 'kitleler' toplumu oluşmuştur. (...) ... toplumların günümüzdeki görünümlerini ve tarihsel aşamaların anlamak için de değerlendirmelerin bu çerçeve içinde yapılması gerekmektedir. (...) Bir kuşaklık bir ömre yakın süredir kitle iletişiminin etkileri altında kalmış ve bu konuda doygunluk noktasına çoktan varmış bir ülkede, sadece böyle tek bir ülkedeki 'nüfusun' üzerinde yapılan araştırma ve çalışmalarla, kitle iletişimi araçlarının - hele hele, kitle iletişimi araçlarının kitle toplumunun oluşumu üzerindeki etkilerinin anlaşılması, açıklanması beklenebilir mi?” Böylesi araştırma ve çalışmalar, Mills’e göre, ancak medyanın tüketici davranışları üzerindeki etkisini merak eden reklamcılar için anlamlı olabilir; "Fakat bu, kitle iletişim araçlarının toplumsal anlamına ilişkin bir kuramın geliştirilmesi için yeterli değildir." (Mills, Toplumbilimsel Düşün, s.86.)

52 Terry Eagleton, Kuramdan Sonra, çev., Uygar Abacı, İstanbul: Literatür Yayınları, 2004. 
her çalışmasını toplumsal bir öneriye adayan Columbia Üniversitesi’nden C.Wright Mills'in Amerikan cultural studies'in kurucularından biri sayılmasi ${ }^{53}$, belki de bu sebepledir.

Sosyal bilimlerin herhangi bir olgusu gibi iletişime ilişkin sorunların da sadece deneysel yöntemlerle veya sadece soyut söylem ve retorik ile cevaplanabileceğini düşünmek ciddi bir hatadır, zira iletişim de, kesinlikle sadece ampirik ve sadece teorik değil, ampirik ve teorik bir nesnedir ve gerçeklik kavramının bu iki yönlü gücü ile çözümlenmelidir. Gerçekliğin bu iki yönlü gücüne hakkını veren bakış ise realist sosyolojik bakıştır. Mesela tarih ve topluma ilişkin "büyük anlatı” döneminin kapandığını ilan eden postmodernist söylem, birey ve özgürlük söz konusu olduğunda, "yeni medya" kullanımında sadece içerik tüketen değil artık içerik de üretmekte olan failleri referans alıyor. Oysaki kitle iletişimine ve onun gelişen teknolojisine yergi ve övgü arasında gidip gelen tek boyutlu bakış ve değerlendirmeler, iletişimin bir sosyal ilişkiler alanı olduğunu bilen ve gözeten sosyal bilimsel yaklaşımlar tarafindan düzeltilmiş bulunuyor. Nihayet, medyaya ilişkin "doğrudan etki” paradigmasının yaydığı tek boyutlu kötümser hava, Lazarsfeld'in -ve sonrasında Katz’ın- yetkin bir sosyolojinin tüm zenginliğini sergileyen çalışmalarıyla dağıtılabilmişti. Benzer şekilde, McLuhan'cı bakışın yücelttiği teknik, Habermas'in bu türden her türlü teknolojik determinizmi reddeden eleştirisiyle demokratik toplumun kamusal alanı için dinamik bir unsuru haline gelmişti. Dolayısıyla iletişim, insanlığın kendi geleceği için umutsuzca bir anlam aradığı böylesi bir tarihsel anda kendisini insanın evriminde en üstün parametreymiş gibi sunuyor. ${ }^{54}$ Oysa özgürlük konusunu, tam da böylesi bir tarihsel anda yüzeysel değil, derinlikli düşünmek gerekiyor. Özgürlük, artık basit anlamda insanın kendi iradesini uygulaması olarak özetlenemez. Çünkü özgürlük, bu iradenin oluşum sürecine egemen olma hakkını da ifade eder ve içerir. Hâlbuki günümüz toplumunun bireyleri, iradelerinin oluşumunda özgür değillerdir. "Bu nedenle, günümüz iletişim teknolojisinin sağladığg yeni olanaklardan yararlanırken, önceliğin, salt katılma olanaklarına değil de, bu yeni katılma olanaklarının yeni bir hayat üslûbu oluşturmaya yatkın kılınmasına verilmesi gerekmektedir." Tabi böyle bir şeyin temel ve önkoşulu, "baskının, korkunun ve bilisizliğin hayatımıza biçim veremeyeceği demokratik bir yaşam ortamı kurulmasıdır." 55

\section{İletişim Bilimsel Epistemoloji: Bir Kitle İletişimi Teorisine Doğru}

İletişim araştırmaları ve kuramlarının kavramsal belirsizliği ve tanımlar arasındaki dengesizlik, sosyal bilimler içindeki tartışmayı bu alana da taşımıştır. Sosyal bilimler alanındaki genel tartışmanın bu özel alan içindeki karşılığı, iletişim kuramları tarihinin, sosyal bilimlerdeki temel bir gerilimin, pozitivizm ile konvansiyonalizm karşıtlı̆̆ının kendini farklı şekillerde dile getirme girişimlerinin tarihi olmasıyla sonuçlanmıştır. Bu bakımdan, iletişim kuramları tarihi, esasen, art arda gelen çeşitli okullar ve akımların ortaya koyduğu doğrusal bir kronoloji değil de, söz konusu gerilim ve karşıtlığın döngüselliğiyle biçimlenen bir gelgitler tarihidir.

53 Mattelart ve Mattelart, İletișim Kuramları Tarihi, s.43-44.

54 Mattelart ve Mattelart, İletişim Kuramları Tarihi, s.147.

55 Oskay, 19. Yüzyıldan Günümüze Kitle İletişiminin Kültürel İşlevleri, s.417. 
$\mathrm{Bu}$ döngüsellik ve gelgitler nedeniyle, iletişim çalışmalarının yaklaşık iki yüzyıla yayılan tarihinde, uzun süreden beri çözüldüğü ve tamamlandığı sanılan inceleme konularının ve stratejilerinin "birdenbire yeniden ortaya çıkışına" ve on yıllar boyunca egemen olan kavrama biçimlerinin, gerçeklik düzenlerinin "yeniden tartışma konusu” oluşuna tanıklık ederiz. ${ }^{56}$ Mesela, demiryolları mühendisliğinden felsefeye geçmiş ve toplumsal fizyolojinin on dokuzuncu yüzyıl ortalarındaki büyük temsilcisi olarak iletişimi "organik bir sistem” sayan düşünceyi geliştirmiş olan Herbert Spencer'in pozitivizmi, yirminci yüzyıl başında ABD'nin refah dönemlerinde egemen düşünceye eşlik eden bir sosyal darwinizmi yansıtan Amerikan pragmatizmi ${ }^{57}$ ile kendini yeniden göstermişti. Benzer şekilde, yirminci yüzyılın ilk yarısında Chicago Okulu'nun Robert E.Park'ın önderliğinde temsil ettiği etnografyacı bakışın, aynı yüzyılın sonunda bütüncü toplumsallık fikrinin gözden düşmesiyle birlikte -mesela Amerikan cultural studies ile- güçlü bir dönüş yapması da yine bu gelgitin çarpıcı örneklerindendir. Veya yirminci yüzyıl sonu ve yirmi birinci yüzyıl başında kitle iletişim araçlarının eriştiği teknolojik düzey karşısında sergilenen teknolojik optimizm ve pesimizm veya teknikçi ütopya ve karşı ütopyacılık, McLuhan’ın teknolojik determinizminin çok belirgin bir biçimidir.

İletişim, "insan durumunun özelliklerinin, öğrenilebilen ve paylaşılabilen biçimlerde simgesel temsili ve yeniden yaratılması bakımından benzersizdir.” İnsanın “önemli olan ve doğru olan nedir" gibi "en geniş insanlaştırıcı mesajlarının üretimi, algılanması ve kavranması" ile ilgili kıymetli bir süreçtir. Geçmişte olduğu gibi bugün de insanın meselelerine ilişkin yeni bir kavrayış arayışı söz konusudur. "Bu arayışın bir bölümü, kitle iletişim araçlarının ve kitle iletişiminin giderek daha önemli bir rol oynadığı olayların gidişatını incelemede, anlamada, değerlendirmede ve denetlemede bize yardımcı olabilecek bir kuram arayışıdır. Bugün böylesi bir kuram yoktur." 58

Kitle iletişim teorisinin bıraktığı miras, iletişim bilimcilere iletişim pratiği üzerine "karmaşık perspektifler" sunmaktadır. Günümüzde yeni medya teknolojilerinin baş döndürücü gelişimi ve yayılımı, bu konunun önemini gittikçe artırıyor. ${ }^{59}$ Yirmi birinci yüzyılın, "new media”, "ağ toplumu” gibi kavramlarında ifade bulan kitle medyasının yarattığı gerçeklik, pozitivist, konvansiyonalist ve sosyolojik bakışı birbirlerini ciddiye almaya itiyor ve itecek gibi görünüyor. Çünkü: "Üç alan da aynı çalışma nesnesini paylaşır, ancak onun farklı yönlerini öne çıkartır.” ${ }^{60}$ Nitekim, Hanno Hardt'ın da belirttiği gibi, iletişim hakkındaki çalışmaların tarihi boyunca, iletişimin toplumsal bağları, bunların birbirinden ayrılamaz oluşu konusunda pek bir anlaşmazlık olmadı. Sorun daha ziyade toplumsal ve iletişimsel süreçlerin incelenmesindeki somut bileşkelerle kavramsal olarak nasıl uğraşmak gerektiği noktasında toplanıyordu. ${ }^{61}$ İçinde bulunduğumuz yüzyılda, "medya pratiğinde gerçekleşen

56 Mattelart ve Mattelart, İletişim Kuramları Tarihi, s.8.

57 Hardt, “Eleştirelin Geri Dönüşü”, s.5.

58 George Gerbner, Kitle İletişim Araçları ve İletişim Kuramı, Erol Mutlu (der. ve çev), Kitle İletişim Kuramları, Ankara: Ütopya Yayınları, 2005, s.76-79.

59 Stevenson, Medya Kültürleri: Sosyal Teori ve Kitle İletişimi, s.345.

60 Stevenson, Medya Kültürleri: Sosyal Teori ve Kitle İletişimi, s.356.

61 Hardt, "Eleştirelin Geri Dönüşüu”, s.12. 
değişimleri yeterli derecede analiz edecek ve bu girişimin daha demokratik akım ve ilgilere nasıl yeniden bağlanabileceğine işaret etmek için gerekli bazı teorik gereçleri sağlamak"62 zorundayı.

İletişim yalnızca şimdi ve burada olana ilişkin değildir, bilinen dünyanın tüm köşelerine ulaşan, toplumsal yaşamın tüm alanlarıyla ilişkisi olan bir yapıya sahiptir. "Medyanın bir sistem olarak gözden geçirilmesi gerekmektedir. Bu, daha büyük ya da daha küçük roller oynayan farklı öğelerdeki sürekli değişim içindeki bir sistemdir. Bunu izleyen şey, özsel olarak politika, ekonomi ve teknoloji ile toplumsal ve kültürel bir tarihtir." ${ }^{63}$ İletişim olgusunun tarihi, bu nedenle, "en gelişmiş sosyal ilişkilerin tarihidir”. ${ }^{64}$ İletişim araştırmaları tarihinde bugüne dek ortaya konulmuş, "meslekten" hiçbir kuram tek başına böylesi geniş bir alanda yetkin bir rehberlik edemez. İletişim sözcüğünün açık bir tanımını vermek istediğimizde, sosyal bilimlerin kurucularının ve mirasçılarının her birinin kendi tarzıyla bizi yönelttikleri o sosyolojik bakış açısina yönelmemiz gerekiyor. Zira doğrudan ya da dolaylı olarak Marx, Tocqueville, Weber ve sosyolojinin başka öncüllerinin çalışmalarında, medya ve iletişim olgusunun karmaşık yapısının incelenmesi için gerekli öğelerin çoğu vardır. ${ }^{65} \mathrm{Bu}$ klasikler, sadece iletişim alanında değil, genel olarak, günümüz gerçekliğinin eleştirisinde sosyal bilimlerin yeniden konumlanışında kullanılabilir durumdadır. Çünkü sosyal teorinin klasik düşünürleri, "modern dünyanın anlamı ve kaderi üzerine aldıkları farklı konumların yarattığı gerilimler alanında" yaşamışlardı. ${ }^{66}$ Graham Murdock, iletişim bilimleri açısından bunu fazlasıyla önemser. Zira Murdock’a göre, kitle iletişimi meselesi bütünlüklü bir bakış açısına ve teoriye ihtiyaç duymaktadır, fakat ihtiyaç duyulan bu teorinin uzmanlaşmış bir "iletişim bilginleri topluluğu” içinde geliştirilmesi mümkün değildir, ancak "insan bilimlerinin merkezi tasarısıyla" bağlantıya geçilerek inşa edilebilecektir. Bu "merkezi tasarı" ise "modernliği anlamak"tır. ${ }^{67}$

Sosyal bilimler, kendi merkezi tasarısına sadık biçimde, modernliği anlamak için kendi tarihinde verimli bir tartışma ortaya koymuştur. "O tartışmanın ana konuşmacılarından biri susturulursa eğer, toplumsal dünya üzerine düşünceler, toplumsal adaletsizliğin yarattığı somut biçimlerle bağdaşamayacak çok soyut bir evrenselliğe ve bu biçimleri etkili biçimde eleştiremeyecek bir tikelliğe kayacak ve dejenere olacaktır." ${ }^{8}$ İletişim teorisi sosyal teorinin eleştirel sesiyle kaynaştığ1 ölçüde felsefi aklın yöneldiği şeyin, yani özgürleşim arayışının bir parçası haline gelebilir. Ne var ki iletişim bilimleri, sosyal teorinin eleştirel potansiyelini kabul etmekteki "başarısızlı̆̆ı" yüzünden, bugün "kendi düşünsel tarihinin kısıtlanımlarını kavrama ve bununla baş etme konusundaki beceriksizliğini” ${ }^{69}$ sürdürüyor görünmektedir.

62 Stevenson, Medya Kültürleri: Sosyal Teori ve Kitle İletişimi, s.23.

63 Asa Briggs ve Peter Burke, Medyanın Toplumsal Tarihi, çev., İbrahim Şener, İstanbul: İzdüşüm Yayınları, 2004, s.12.

64 Frédéric Barbier ve Catherine Bertho Lavenir, Diderot'dan İnternete Medya Tarihi, çev., Kerem Eksen, İstanbul: OkuyanUs Yayınlar1, 2001, s.11.

65 Maigret, Medya ve İletişim Sosyolojisi, s.21.

66 Callinicos, Toplum Kurami, s.467

67 Graham Murdock, İletișim, Modernlik ve İnsan Bilimleri, s.365.

68 Callinicos, Toplum Kuramı, s.468.

69 Hardt, "Eleştirelin Geri Dönüşü", s.48. 


\section{Sonuç}

Modern toplumları anlamak için kendisine merkezi bir rol verilmesi gereken kitle iletişimini maddi (ekonomi-politik) ve sembolik (ideolojik) boyutlarıyla açıklayabilmek gerekiyor. Hem iletişimin bu iki boyutu arasındaki bağı hem de onun modern toplumlarla olan bağını ortaya koyabilmek için iletişim bilimlerinin eleştirel bir sosyolojik yaklaşıma ihtiyacı vardır. Böyle bir yaklaşıma sahip olduğunda sosyal bilimler alanında özgün bir disiplin olma niteliğini kesinleştirecektir. Uzmanlık alanının benzersiz nesnesinin toplumsal gerçekliğin bütünüyle olan ilişkisini hesaba katan bir iletişim bilimci, kaçınılmaz biçimde, felsefe ile bağ kuracaktır. Çünkü felsefi aklın yöneldiği şey, yani özgürleşim arayışı, eleştirel sosyolojinin epistemolojik öğesidir, hatta o epistemolojinin mütemmim cüz'üdür.

İletişim bilimleri, kendi epistemolojisinin temelini bu arayışın ilkeleriyle kurmalıdır. Alan içinde halihazırda var olagelmiş bilgi iddialarını, bunlar genel olarak sosyal teorinin temel epistemolojik sorunlarını dile getirdiği için, gözden geçirmelidir. İletişim araştırmaları tarihinin sunduğu "karmaşı perspektifler" içerisinde belirginleşebilmiş geleneklerden herhangi birinin iletişim olgusu hakkındaki kendi bilgi iddiasına ilişkin sistematik bir tartışma üretmemiş olması bugünün ve geleceğin iletişim bilimcilerinin önüne bir ödev koymaktadır. Sosyal olguların yapısı ve dinamiğiyle ilgili bir tartışmayı sosyal bilimlerin konuları arasına katmaktan kaçınamayacağımız gibi, iletişim bilimlerinin konuları arasına da bir olgu olarak iletişimin yapısı ve dinamiğiyle ilgili bir tartışmayı katmaktan kaçınamayız. Olguların yapısı ve dinamiğini anlama ise tam da epistemolojinin amacıdır. Bizzat bu anlama çabasının kendisi felsefeyle iç içe geçmiş durumdadır.

\section{Kaynakça}

Adorno, Theodor. Otoritaryen Kişilik Üstüne. Çev. Doğan Şahiner. İstanbul: Say Yayınlar1, 2011.

Anderson, Perry. Batı'da Sol Düşünce. Çev. Bülent Aksoy. İstanbul: Birikim Yayınları, 1982.

Barbier, Frédéric ve Catherine Bertho Lavenir. Diderot'dan Internete Medya Tarihi. Çev. Kerem Eksen. İstanbul: OkuyanUs Yayınları, 2001.

Bauman, Zygmunt. Modernlikve Müphemlik. Çev. İsmail Türkmen. İstanbul: Ayrıntı Yayınları, 2003.

Bloch, Ernst. Rönesans Felsefesi. Çev. Hüsen Portakal. İstanbul: Cem Yayınevi, 2002. Bloch, Ernst. Umut İlkesi. Cilt 1. Çev. Tanıl Bora. İstanbul: İletişim Yayınları, 2007.

Bottomore, Tom. "Marxizm ve Sosyoloji". Bottomore, Tom ve Robert Nisbet (der.), Sosyolojik Çözümlemenin Tarihi. Çev. Mete Tunçay ve Aydın Uğur. İstanbul: Verso Yayınları, 1990: 134-164.

Bottomore, Tom ve Maximilien Rubel. Marx’ın Sosyolojisi. Çev. Zuhal Bilgin. İstanbul: Çiviyazıları Yayınları, 2006.

Bottomore, Tom ve Robert Nisbet. "Yapisalc1lık". Bottomore, Tom ve Robert Nisbet (der.), Sosyolojik Çözümlemenin Tarihi. Çev. Mete Tunçay ve Aydın Uğur. Ankara: Verso Yayınları, 1990: 572-612. 
Bourdieu, Pierre. Toplumbilim Sorunları. Çev. Işık Ergüden. İstanbul: Kesit Yayınları, 1997.

Briggs, Asa ve Peter Burke. Medyanın Toplumsal Tarihi. Çev. İbrahim Şener. İstanbul: İzdüşüm Yayınları, 2004.

Callinicos, Alex. Toplum Kuramı. Çev. Yasemin Tezgiden, İstanbul: İletişim Yayınları, 2004.

Cang1zbay, Kadir (der). Gurvitch: Sosyoloji ve Felsefe. Ankara: Ütopya Yayınları, 1999.

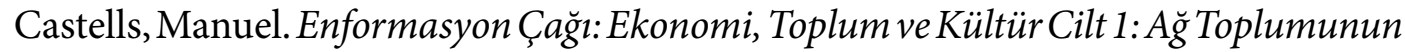
Yükselişi. Çev. Ebru Kılıç. İstanbul: Bilgi Üniversitesi Yayınları, 2005.

Chaffe, Steven H. ve Charles R. Berger. “İletişim Bilimci Ne Yapar?”. Erol Mutlu (der. ve çev.). Kitle İletişim Kuramları. Ankara: Ütopya Yayınları, 2005: 42-74.

Duverger, Maurice. Sosyal Bilimlere Giriş. Çev. Ünsal Oskay. İstanbul: Bilgi Yayınevi, 1999.

Eagleton, Terry. Postmodernizmin Yanılsamaları. Çev. Mehmet Küçük. İstanbul: Ayrıntı Yayınları, 1999.

Eagleton, Terry. Kuramdan Sonra. Çev. Uygar Abacı. İstanbul: Literatür Yayınları, 2004.

Engels, Friedrich. Anti-Dühring. Çev. Kenan Somer. Ankara: Sol Yayınları, 1977.

Freund, Julien. "Max Weber Zamanında Alman Sosyolojisi”. Bottomore, Tom ve Robert Nisbet (der.). Sosyolojik Çözümlemenin Tarihi. Çev. Mete Tunçay ve Aydın Uğur. Ankara: Verso Yayınları, 1990: 165-198.

Gerbner, George. "Kitle İletişim Araçları ve İletişim Kuramı”. Erol Mutlu (der. ve çev.). Kitle İletişim Kuramları. Ankara: Ütopya Yayınları, 2005: 75-100

Giddens, Anthony. Siyaset, Sosyoloji ve Toplumsal Teori. Çev. Tuncay Birkan. İstanbul: Metis Yayınları, 2000.

Hardt, Hanno. "Eleştirelin Geri Dönüşü ve Radikal Muhalefetin Meydan Okuyuşu: Eleştirel Teori, Kültürel Çalışmalar ve Amerikan Kitle İletişim Araştırması”. Küçük, Mehmet (der. ve çev.). Medya, İktidar, İdeoloji. Ankara: Ark Yayınevi, 1994: 1-55.

Hobsbawm, Eric J. Imparatorluk Çağı 1875-1914. Çev. Vedat Aslan. Ankara: Dost Kitabevi, 1999.

Jameson, Fredrick. Modernizm İdeolojisi. Çev. Kemal Atakay, Tuncay Birkan. İstanbul: Metis Yayınları, 2008.

Jeanneney, Jean-Noel. Başlangıcından Günümüze Medya Tarihi. Çev. Esra Atuk. İstanbul: Yapı Kredi Yayınları, 2009.

Keat, Russel ve John Urry. Bilim Olarak Sosyal Teori. Çev. Nilgün Çelebi. Ankara: İmge Kitabevi, 2001.

Lang, Kurt. "İletişim Araştırmaları: Kökenleri ve Gelişmesi”. Erol Mutlu (der. ve çev.). Kitle İletişim Kuramları. Ankara: Ütopya Yayınları, 2005: 27-41.

Maigret, Éric. Medya ve İletişim Sosyolojisi. Çev. Halime Yücel. İstanbul: İletişim Yayınları, 2011.

Marx, Karl. “Mutlak Eleştirel Eleştiri”. Marx, Karl ve Friedrich Engels. Kutsal Aile. Çev. Kenan Somer. Ankara: Sol Yayınları, 2003: 110-191. 
Mattelart, Armand ve Michèle Mattelart. İletişim Kuramları Tarihi. Çev. Merih Zıllığlu. İstanbul: İletişim Yayınları, 2006.

Mills, C. Wright. Marksistler. Çev. T. Hasan. İstanbul: Ağaoğlu Yayınları, 1966.

Mills, C. Wright. Toplumbilimsel Düşün. Çev. Ünsal Oskay. Ankara: Kültür Bakanlığ 1 Yayınları, 1979.

Murdock, Graham. “İletişim, Modernlik ve İnsan Bilimleri”. Küçük, Mehmet (der. ve çev.). Medya, İktidar, İdeoloji. Ankara: Ark Yayınevi, 1994: 365-381.

Oskay, Ünsal. 19. Yüzyıldan Günümüze Kitle İletişiminin Kültürel İşlevleri. İstanbul: Der Yayınları, 1993.

Poloma, Margaret M. Çăgdaş Sosyoloji Kuramları. Çev. Hayriye Erbaş. Ankara: Eos Yayınevi, 2007.

Rosenau, Pauline Marie. Post-Modernizm ve Toplum Bilimleri. Çev. Tuncay Birkan. Ankara: Ark Yayınları, 1998.

Stevenson, Nick. Medya Kültürleri: Sosyal Teori ve Kitle İletişimi. Çev. Göze Orhon, Barış Engin Aksoy. Ankara: Ütopya Yayınları, 2008.

Thompson, John B. Medya ve Modernite. Çev. Serdar Öztürk. İstanbul: Kırmızı Yayınları, 2008.

Turner, Stephen P. (der.). Sosyal Teori ve Sosyoloji: Klâsikler ve Ötesi. Çev. Ümit Tatlıcan. İstanbul: Küre Yayınları, 2008.

Wallerstein, Immanuel. Bildiğimiz Dünyanın Sonu. Çev. Tuncay Birkan. İstanbul: Metis Yayınları, 2000.

Winch, Peter. Sosyal Bilim Düşüncesi ve Felsefe. Çev. Ömer Demir. Ankara: Vadi Yayınları, 2007.

Wood, Ellen Meiksins. "Postmodern Gündem Nedir?" Wood, Ellen Meiksins ve John Bellamy Foster (der.). Marksizm ve Postmodern Gündem. Çev. Ahmet Fethi. Ankara: Ütopya Yayınları, 2001: 7-26. 


\title{
The Relation Between Communication Sciences and Philosophy in Social Sciences in the Process of Becoming a Discipline
}

GÖKSEL AYMAZ

\begin{abstract}
Communication sciences proceeding as a distinctive discipline within the scope of social sciences was not able to establish a proper relationship with philosophy. However, this problem stems from the epistemological difficulty of defining "phenomenon" in social sciences. "Audience research", "discourse analysis" and "critical approach" traditions corresponding to "positivist", "conventionalist" and "realist" epistemologies in social sciences, express various perspectives in the relation between communication sciences and philosophy. Our article renders the idea that the inheritance of mass communication theory presents communication scientists with "complicated perspectives" on communication practices. Within this variety, it is asserted that communication sciences aspiring to position itself as a distinctive discipline is supposed to adopt a perspective making it establish a closer relationship with philosophy. Based on the fact that social sciences are not a science of "social facts" but of "social phenomenon", it is asserted that communication sciences, being a scope of the phenomenon should always be in a close relationship with philosophy, being a scope of tenets. In this context, "realist epistemology" and "critical approach" are suggested.
\end{abstract}

Keywords: Communication sciences, Philosophy, Social sciences, Phenomenon, Epistemology. 